\title{
単独測位GPSの測位精度と茶園における利用の検討
}

\author{
独立行政法人 農業・生物系特定産業技術研究機構 野菜茶業研究所* \\ 荒木环也・深山大介・宮崎昌宏 \\ (平成17年 3 月 11 日受理)
}

\section{Accuracy of SPS-GPS and Application to Tea Field Management}

\author{
Takuya Araki, Daisuke Miyama and Masahiro Miyazaki \\ National Institute of Vegetable and Tea Science \\ National Agriculture and Bio-oriented Research Organization
}

\section{Summary}

In this study, accuracy and availability of SPS-GPS (Standard Positioning Service GPS) receiver as a positioning device was evaluated by a fixed-point and site test in a tea field. The SPS.GPS has a positioning precision of about $5.33 \mathrm{~m}$ ( $2 \mathrm{~d}$ RMS) with continuous observation for 12 hours at fixed-point. By using GPS, plotting and computing $1349 \mathrm{~m}^{2}( \pm 3 \%)$ area of tea field can be done easily in 13 minutes by a single operator. Therefore, GPS has sufficient accuracy, and is a simple device to collect geographical information.

Key Words : GPS, GIS, Tea Field Management

\section{1 緒言}

合理的かつ効率的な茶園管理には，茶樹の 生育, 栽植状態や茶園土裹環境など茶園状態 の把握や管理下にある茶園の気温や雨量等の 気象環境や傾斜度, 斜面方向など園地特性を 把握することが必要である。薬凧や肥料など の資材の投入量の算出や単位面積あたりの収 量などを求めるには茶園面積が必要であるが, 基盤整備が行われていない茶園の多くは面積 が正確に把握されていない。また, 荒茶加工 の担い手の減少や加工施設の経営の改善の必 要性から再編整備が推進され, 製茶施設は大 型化しており，製茶施設を利用する茶園の数 は増加していると考光られ，多数の茶園を効 率的に管理する必要性がある。このような状
況のなか, 数多くの茶園の農地管理や生産管 理を効率的に行い, 生産性を向上させるため にGIS (地理情報システム)の活用が求められ ている。しかし, GISの基盤となる地理情報の 整備は進んで㧈らず, 幹線道路から離れた作 業道などは既製の地図に記載されていないこ とが多い。さらに茶園の現状を反映した詳細 な地理情報は容易に取得できない。そこで, GPS (Global Positioning System)による地 理情報の取得および利用が注目されるように なってきた。

GPSは, アメリカ合衆国が開発・運用して いる人工衛星を用いた位置決定のためのシス テムである。今日，カーナビゲーションシス テムをはじめとして, 高精度のものは測量に も用いられるようになった。GPS衛星は地球

“ ₹428-8501 静岡県島田市金谷2769 
の赤道面に対して55度傾いた 6 枚の軌道面上, 高度約 $20,000 \mathrm{~km}$ に 4 個ずつ合計24個配置さ れ，その周回周期は 0.5 恒星日である。

測位の仕組みは, 軌道上の位置がわかって いる複数のGPS衛星からGPS受信機までの信 号到達時間をもとにGPSアンテナの位置を計 算する。信号到達時間をもとに距離を算出す るためGPS衛星には正確な時刻を刻む原子時 計が組み込まれている。緯度, 経度, 高さ, 受信機の時計の愦差の 4 つの未知数を得るた めに 4 機のGPS衛星の信号到達時間から時刻 の同期を行い，測位を行う。

GPS測位方式には単独測位方式と相対測位 万式とがある。単独測位はGPSのもっとも基 本的な利用法で, カーナビゲーションシステ ムや船舶用，レジャー用途などに利用されて いる。市販されている受信機の価格は数万円 からある。GPS衛星からの電波のみにより測 位する方式であるため, 軽装備にでき, 電源 は乾電池やコンピュータから供給される方式 のものが多い。衛星からの電波が受信できる 場所で利用可能である。相対測位方式にはディ ファレンシャルGPS (以下D-GPS), 干涉測 位がある。D-GPSは既知の点の測位誤差情報 を, 未知点へ伝送し, 未知点での測位結果を 補正して精度を改善する方式である。日本で は海上保安庁の中波ビーコン, FM多重により 補正情報を受信できる。精度は数的と言われて いる。衛星からの電波のほ加補正情報用電波 の受信装備が必要であり, 補正情報が受信で きる場所でないと性能を発揮できない。干涉 測位方式はGPS衛星からの電波の搬送波の位 相を測定し測位を行う方式で，キネマティッ ク方式，スタティック方式がある。精度は後 処理を行う場合, 数 $\mathrm{mm}$, 実時間測位で数 $\mathrm{cm}$ と 言われている。一般に固定局と移動局を一組 にして測位を行うため重装備である。

農業においては，作業機械の位置認識や自 動操舵に干渉測位方式の高精度GPSの利用が 試みられている2 。また, ディファレンシャ ルGPS, GISを用いた土裹調查支援システムが 開発されている8)。しかし, 単独測位方式のGPS については利用されていない現状にある。
元来，GPSは軍事目的に開発されたため， 民間利用においては測位精度を低下させる信 号 (Selective Availability:S/A) が出され ていたが，2000年 5 月にそれが解除された。 このため測位精度は基本的な構成の単独測位 GPSにおいても $100 \mathrm{~m}$ 程度から $10 \mathrm{~m}$ 程度に改善 されたといわれており, 位㯰情報の取得手段 として実用的なシステムになってきだ。

そこで本報では，近年精度の向上があり， 軽装備で容易に取り扱え低コストであるなど のメリットがある単独測位GPSを用いて，そ の測位精度を調査し, 茶園面積計測やGISの構 築など茶園管理への利用を検討した。

なお，本研究以農業・生物系特定産業技術 研究機構の交付金プロジェクト「消費者に信 頼される生産体系を支える精密畑作農業技術 の開発」の一環で行ったものである。

\section{2 方法}

供試したGPS受信機の仕様を表 1 に示す。 単独測位GPSはコンパクトフラッシュカード 型GPS受信機（日本無線株式会社製，NNN $-310 \mathrm{TA}$, 外形寸法 $57.0 \mathrm{~mm}(\mathrm{~W}) \times 74.3 \mathrm{~mm}$

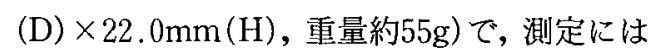
外部GPSアンテナ（日本無線株式会社製, NAY-3700M5, 外形寸法 $41 \mathrm{~mm}(\mathrm{~W}) \times 50$ $\mathrm{mm}(\mathrm{D}) \times 15 \mathrm{~mm}(\mathrm{H})$, 重量約 $115 \mathrm{~g})$ を使用し た。 L 1 帯 $(1575.42 \mathrm{MHz})$ の 8 チャンネルの 受信が可能で, 民間向けのC/Aコードの符号 を利用して測位を行った結果をNMEA0183 フォーマットで 1 秒毎に出力する。電源はコ ンピュータより供給される。

\section{表 1 供試GPS受信機の仕様}

\begin{tabular}{|c|c|}
\hline 型式 & NNN-310TA \\
\hline $\begin{array}{l}\text { 外形寸法 [mm], } \\
\text { 質量 }[\mathrm{g}]\end{array}$ & $\begin{array}{l}57.0(\mathrm{~W}) \times 74.3(\mathrm{D}) \times \\
22.0(\mathrm{H}), 55\end{array}$ \\
\hline インターフェース & $\begin{array}{l}\text { コンパクトフラッシュ } \\
\text { TypeII }\end{array}$ \\
\hline 受信方式 & $\begin{array}{l}\text { マルチチャンネル } \\
\text { (8チャンネル) }\end{array}$ \\
\hline 受信周波数 & $1575.42 \mathrm{MHz}$ \\
\hline 出カフォーマット & NMEA0183 \\
\hline
\end{tabular}


測位精度を調べるための測位データの収録 は自作のアプリケーションを用い, ノート型 パソコンで行った。緯度, 経度, 高さのほか 受信衛星数, 受信状態の把握のため信号対， イズ比(SNR), 測位点と衛星の配置との幾何 学的関係による測位精度への影響を示す精度 低下率 (Dilution Of Precision, 以下DOP), 位置精度低下率 (PDOP), 水平位置精度低下 率（HDOP）を取得できる。茶園属性データ の取得, 解析にはGISデータ収集ソフトウェア （株式会社アカサカテック製SOLO-FIELD, Version 3.3.1) を用いPDA (PocketPC, 日 本ヒューレット・パッカード株式会社製 h 2210) でおこなった。

本報では, GPSからの出力にはWorld Geodetic System 1984 (WGS- -84) と呼ばれ る座標系を, 三角点の緯度, 経度には国土地 理院の世界測地系（測地成果2000）と呼ばれ る座標系を用いた。ともに地球中心を原点と した地心測地座標系である。準拠棈円体の扁 平率がごく僅かに異なるものの，この影響は 僅かであるため9), 本報では等しいものとして 扱った。また高さについては, WGS-84系に よるジオイドからの高さを高さとし, 測地成果 2000による水準面からの高さを標高と記した。

計測結果の精密度（ばらつきの程度）は, 水平面を対象として誤差円半径 $(2 \times$ distance root mean square, 以下 $2 \mathrm{dRMS})$ [m] で表 した。2 dRMSは測位誤差が典型的な分布をす る場合, 誤差のうち $95 \%$ 崖その範囲に入るた め，GPSの精度を示す指標として用いられて いる。緯度および経度の距離への変換は, 緯 度方向 $30.8 \mathrm{~m} /$ 秒, 経度方向 $25.4 \mathrm{~m} /$ 秒で計算 した。

\section{1 単独測位GPSの測位精度}

利用可能な衛星数や受信状態の変化を調べ るために, 野菜茶業研究所（静岡県榛原郡金 谷町）内の圃場において, 周囲が開け上空に 信号を遮蔽する障害物の無い受信条件が良い と考えられる茶園 (アンテナ高地上 $1.5 \mathrm{~m}$, 以 下A地点) と,アンテナ上部より南側を樹木 (樹 高 8-13m)に囲まれ，受信条件が悪いと考え
られる茶園 (アンテナ高地上 $1.0 \mathrm{~m}$, 以下B地 点）にアンテナを設置して，単独測位による 12時間の連続測定を行った。測定は，2002年 8 月19～20日 (A地点), 同21～22日 (B地点) にかけて，1秒間隔でデータを収録した。

単独測位GPSの測位結果の再現性を検証す るため, 測位結果の年間変動を，2004年にC 地点（周囲が開け上空に信号を遮蔽する障害 物の無いにに扔いて計測した。計測は毎月行い, 5 分間 (300点) の平均値を測位結果とした。

\section{2 三角点測位試験}

単独測位の測位精度を検証するため，位置 座標が正確に求められている三角点に測位点 を設けて，測定を行った。測位点には四等三 角点(基準点コード5238-11-6001, 点名 牧 八原, 北緯 $34^{\circ} 48^{\prime} 37^{\prime \prime} .6996$, 東経 $138^{\circ}$ 7'43".4955 (世界測地系)，標高213.74m）を 用いた。三角点は牧之原台地の茶園内にあり 上空に信号を遮蔽するものはなかった。GPS アンテナはポールを用いて,三角点の真上 1.5 $\mathrm{m}$ に設置した。測定は，2002年 8 月29日10時 〜11時にかけて, 1 秒間隔でデータを収録した。

\section{3 茶園属性デー夕収集への応用}

茶園属性デー夕収集への単独測位GPSの適 用を調査する目的で, 茶園形状, 面積および 栽植様式の取得を試みた。約 $13.5 \mathrm{a}, 11$ ねの 茶園を供試し, 茶園を7 角形として取得した。 またうね配置はうねの両端の位置を記録した。 1 点あたりの測位にかける時間について 5 秒

(概ね 5 回サンプリング) ${ }^{10)}$ や10秒(概ね 10 回

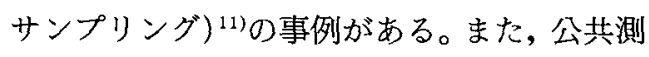
量作業にネットワーク型RTK一GPSを利用す る場合，1点あたりの観測回数を10回以上と することが提案されている ${ }^{12)}$ 。本試験では 10 オ゙ー 夕（概ね 10 秒間）をサンプリングし平均化し た值を測位結果とした。計測作業は 1 人で行 い, 茶園外周を歩行し頂点およびうねの端点 を記録した。

測定は，2004年 9 月28日10時～12時にかけ て行った。点間距離抽よび面積を測量機によ り計測した実測值と比較した。 


\section{3 試験結果および考察}

\section{1 衛星受信状態}

測定点において単独測位で得られた緯度， 経度, 高さ,GPS受信機が捉えた衛星数, PDOP の比較を表 2 に, 受信衛星数, PDOPの時間変 化を図 1 に示す。受信衛星数はA地点では 6 を下回ることがなく,平均7.7個のGPS衛星を 捉えていた。B地点では，測定中平均6.5個の GPS衛星を捉えていたが，午前 1 時から午前 5 時の間は衛星数の変動が大きく, 3 次元測 位に最低限必要な 4 を下回ることがあった。 12 時間の測位結果の精密度は $\mathrm{A}$ 地点では水平

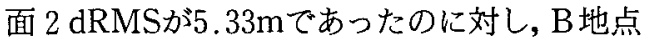
では10.2mであり，誤差円面積は 4 倍であった。 測位に利用される衛星はGPSアンテナ内部で 決定されるが, PDOPはA地点では平均 2.0 と 良好であったのに対し，B地点では平均 2.5 と 受信状態は $\mathrm{A}$ 地点に比べ劣った。PDOPは 3 以 下が好ましいとされるが13), PDOPが，3より 大となる時間の割合は $\mathrm{A}$ 地点で $0 \%, \mathrm{~B}$ 地点で
$19.3 \%$ と，測位地点の状洗によりGPSの利用 に適さない時間が出現することがわかった。 PDOPが 3 より大となる時間带は衛星数が少な い，午前 1 時から午前 5 時の間だった。この ような時間带は精度の低下が認められたこと から,フィールドでの計測中はPDOPあるいは 衛星数のいずれかをモニターすることで，測 位精度の劣るデー夕を除去できると考えられた。 衛星方位角によるSNRの分布の状態を図 2 に示す。測位点において受信機が捉えた衛星 のSNRは, A 地点で平均 $49.3 \mathrm{~dB}, \mathrm{~B}$ 地点で平 均45.1dBであった。南側を樹木に遮られたB 地点では, 南側 $\left(90^{\circ}-270^{\circ}\right)$ にある衛星からの SNRが低く,SNRの低下は樹木による信号の 減衰の影響によると考えられた。

\section{2 測位結果の年間変動}

2004年 1 月から同年12月にC地点において 測位した結果，年間12点の水平面 $2 \mathrm{dRMS}$

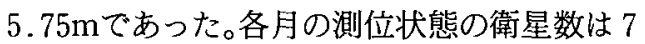
〜 8 個, PDOPは1.5〜2.4であり $2 \mathrm{dRMS}$ 最

表 2 連続測位結果（静岡県榛原郡金谷町）

\begin{tabular}{|c|c|c|c|}
\hline \multicolumn{2}{|l|}{ 測位点 } & $\begin{array}{l}\text { A地点 } \\
2002 \text { 年 } 8 \text { 月19-20日 }\end{array}$ & $\begin{array}{l}\text { B地点 } \\
2002 \text { 年 } 8 \text { 月 } 21-22 \text { 日 }\end{array}$ \\
\hline \multirow{4}{*}{ 緯 } & 平均 & $34^{\circ} 48^{\prime} 255466^{\prime \prime}$ & $24^{\circ} 48^{\prime} 32826^{\prime \prime}$ \\
\hline & 最大 & $34^{\circ} 48^{\prime} 25.9080^{\prime \prime}$ & $34^{\circ} 48^{\prime} 31.9800^{\prime \prime}$ \\
\hline & 最小 & $34^{\circ} 48^{\prime} 25.3200^{\prime \prime}$ & $34^{\circ} 48^{\prime} 30.6660^{\prime \prime}$ \\
\hline & $2 \sigma$ & $0.0726^{\prime \prime}$ & $0.1409^{\prime \prime}$ \\
\hline \multirow[t]{4}{*}{ 経 度 } & 平均 & $138^{\circ} 07^{\prime} 57.0726^{\prime \prime}$ & $138^{\circ} 08^{\prime} 02.1183^{\prime \prime}$ \\
\hline & 最大 & $138^{\circ} 07^{\prime} 57.2820^{\prime \prime}$ & $138^{\circ} 08^{\prime} 02.9700^{\prime \prime}$ \\
\hline & 最小 & $138^{\circ} 07^{\prime} 56.7780^{\prime \prime}$ & $138^{\circ} 08^{\prime} 01.5240^{\prime \prime}$ \\
\hline & $2 \sigma$ & $0.0570^{\prime \prime}$ & $0.1069^{\prime \prime}$ \\
\hline \multicolumn{2}{|c|}{ 水平面 $2 \mathrm{dRMS}$ [m] } & 5.33 & 10.2 \\
\hline \multirow[t]{4}{*}{ 高さ[m] } & 平均 & 208.1 & 204.8 \\
\hline & 最大 & 217 & 227 \\
\hline & 最小 & 191 & 158 \\
\hline & $2 \sigma$ & 3.0793 & 6.8243 \\
\hline PDOP & 平均 & 2.0 & 2.5 \\
\hline \multirow[t]{3}{*}{ 衛星数 } & 平均 & 7.7 & 6.5 \\
\hline & 最大 & 8 & 8 \\
\hline & 最小 & 6 & 0 \\
\hline
\end{tabular}


小 $3.01 \mathrm{~m}$ (9月), 最大 $6.14 \mathrm{~m}$ ( 2 月) だった

(表 3 )。PDOPおよび衛星数がばらつきの程

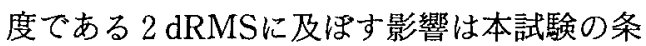
件では認められなかった。高さについては平 均 $205.5 \mathrm{~m}$, 標準偏差 $5.2 \mathrm{~m}$ で, $218.0 \mathrm{~m}$ ( 1 月) $-199.8 \mathrm{~m}$ (10月) と最大 $18.2 \mathrm{~m}$ 差が生じた。 測位結果のばらつきは, 緯度方向で経度方向 より大きかったが，一定の傾向は認められな かった(図 3)。良好な条件下での単独測位GPS による測位の再現性は, 年間を通して半径約 $6 \mathrm{~m}$ 程度の円となる。茶園や防霜ファンの特定 などに利用できると考えられた。

\section{3 三角点における単独測位の精度}

測位結果を表 4 に示す。緯度, 経度, 高さ はWGS-84座標系による600回の測定值の平 均, 標準偏差である。測位結果と三角点の測 地成果との座標值の差は国土地理院のプログ ラムデータを用いて，準拠楕円体をGRS80と して, 距離 $[\mathrm{m}] に$ 換算して誤差として求めた。 測位結果と測地成果との誤差は南北（緯度） 方向で $1.21 \mathrm{~m}$, 東西 (経度) 方向で $0.645 \mathrm{~m}$, 距離で $1.37 \mathrm{~m}$, 高さで $3.24 \mathrm{~m}$ であった。計測中
の水平面 $2 \mathrm{dRMS} 1.56 \mathrm{~m}, \mathrm{PDOP} 1.9$ であ り，受信状態は良好であった。

測定に利用した三角点は茶園内にあり周囲 が開けて，受信状態が良かったため，単独測 位としては極めて高い精度で測位できたと考 えられた。また， 2 dRMSが小さかったのは計 測時間が10分間と短く，測位結果のドリフト の影響が少なかったためと考えられた。計測 時間を短くすることで，ドリフトの影響が少 なくなると考えられるが，年間のばらつきを 考慮すると，単独測位GPSにより詳細な地理 情報を得ることは困難であると考えられる。 今回の詔差 $1.37 \mathrm{~m}$ は茶園の境界や茶うねを識 別するような, 詳細なGIS構築への適用には精 度が不足すると考えられるが，1/1000の地形 図上では, 約 $1.4 \mathrm{~mm}$ であり,デジタルマップ 上で茶園の位置を特定するなど, 簡易な情報 取得手法として利用できると判断された。

\section{4 茶園情報の取得}

約13.5a，11うねの茶園を供試し，茶園形状， 面積，うね配置の取得をした(図 4 )。作業に 要した時間は衛星信号を受信し測位結果が安

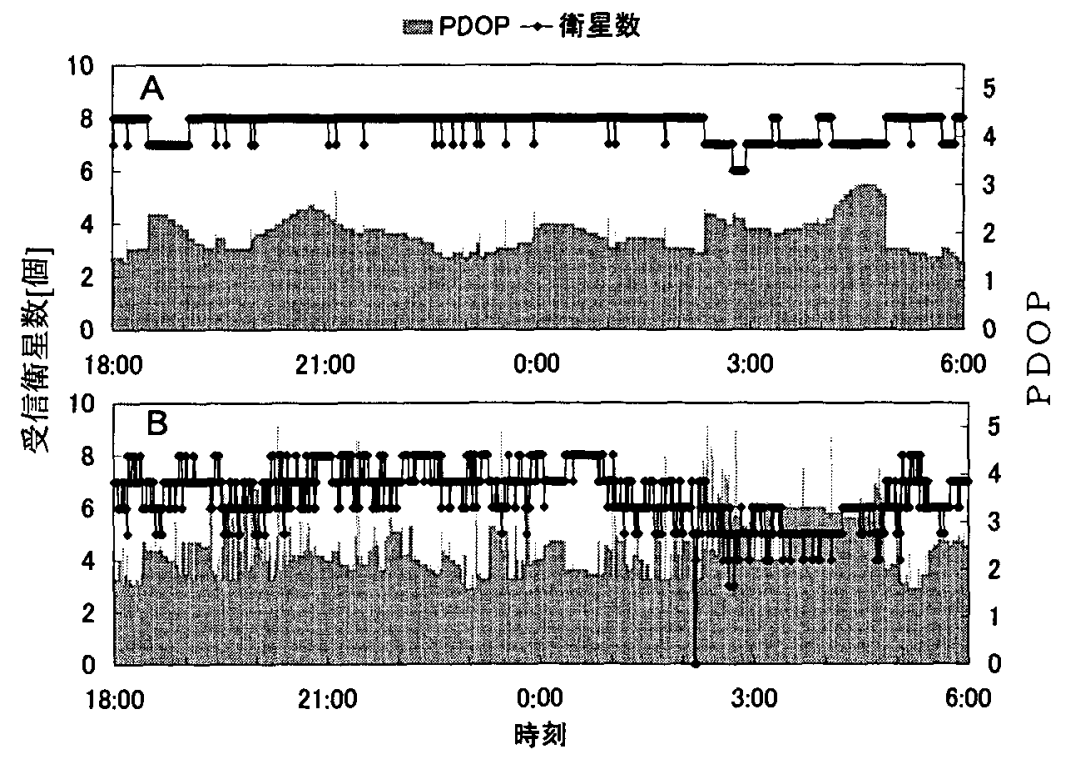

図 1 障害物の有無が受信衛星数およびPDOPに及ほす影響

A：障害物なし2002年 8 月19-20日

B：障害物あり 2002 年 8 月 $21-22$ 日 

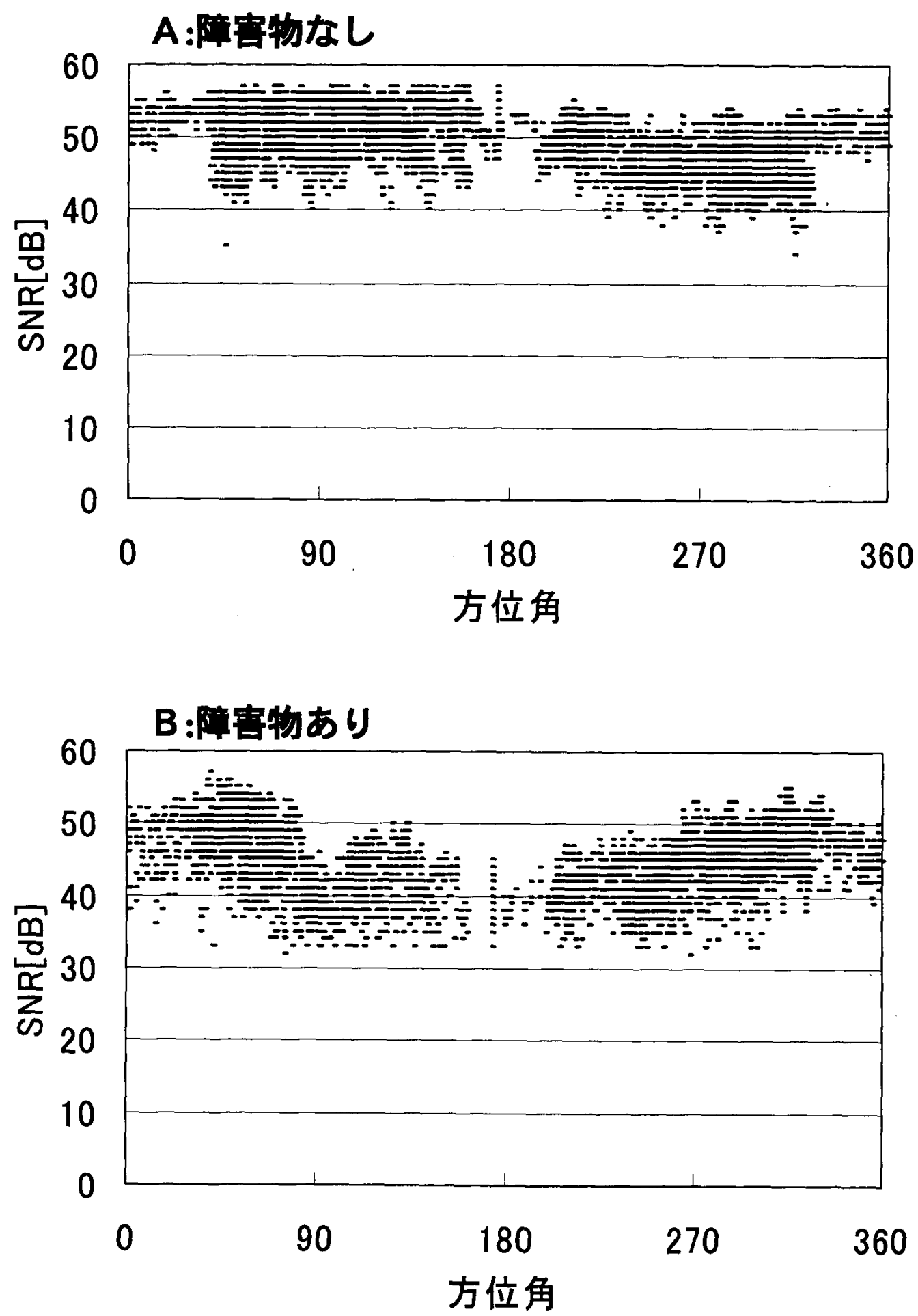

図 2 衛星方位角の違いによるSNRの变化 方位角は $0^{\circ}, 90^{\circ}, 180^{\circ}, 270^{\circ}$ の順に北、東、南、西 
表 3 測位結果および受信状態の年間変動(2004年)

\begin{tabular}{|c|c|c|c|c|c|c|c|c|c|}
\hline \multirow[b]{2}{*}{ 月 } & 日 & \multicolumn{2}{|c|}{ 時 } & \multicolumn{2}{|c|}{ 結 } & 果 & \multicolumn{2}{|c|}{ 状 } & 態 \\
\hline & 日 & 時 & 刻 & 緯度 [秒] & 経度 [秒] & 高さ [m] & $2 \mathrm{dRMS}[\mathrm{m}]$ & 衛星数 & PDOP \\
\hline 1 & 16 & $12: 00: 00$ & 12:04:59 & 27.2948 & 57.6055 & 218.0 & 5.28 & 8.0 & 2.4 \\
\hline 2 & 26 & $12: 00: 00$ & $12: 04: 59$ & 27.4235 & 57.7158 & 204.9 & 6.14 & 7.8 & 1.8 \\
\hline 3 & 23 & $12: 00: 00$ & $12: 04: 59$ & 27.4938 & 57.6233 & 210.1 & 4.18 & 7.0 & 2.1 \\
\hline 4 & 23 & $14: 30: 00$ & $14: 34: 59$ & 27.4690 & 57.6902 & 202.3 & 3.93 & 8.0 & 2.3 \\
\hline 5 & 18 & 10:30:00 & $10: 34: 59$ & 27.4603 & 57.6611 & 211.3 & 5.94 & 8.0 & 1.5 \\
\hline 6 & 16 & $12: 35: 00$ & $12: 39: 59$ & 27.3606 & 57.5058 & 205.5 & 4.59 & 8.0 & 1.8 \\
\hline 7 & 14 & $11: 30: 00$ & $11: 34: 59$ & 27.3460 & 57.5526 & 203.7 & 3.26 & 8.0 & 1.7 \\
\hline 8 & 16 & $12: 30: 00$ & $12: 34: 59$ & 27.3088 & 57.6575 & 201.3 & 3.13 & 7.9 & 1.9 \\
\hline 9 & 21 & $12: 15: 00$ & 12:19:59 & 27.4359 & 57.5855 & 204.8 & 3.01 & 8.0 & 1.7 \\
\hline 10 & 22 & $09: 45: 00$ & 09:49:59 & 27.3837 & 57.5753 & 199.8 & 3.95 & 8.0 & 1.6 \\
\hline 11 & 24 & $11: 15: 00$ & $11: 19: 59$ & 27.3457 & 57.5746 & 202.4 & 4.43 & 8.0 & 1.7 \\
\hline 12 & 17 & $11: 50: 00$ & $11: 54: 59$ & 27.2725 & 57.7397 & 202.1 & 4.79 & 8.0 & 1.9 \\
\hline
\end{tabular}

表中の緯度および経度はそれぞれ $34^{\circ} 48^{\prime}$ おるび $138^{\circ} 07^{\prime}$ 以下の值を記載した。

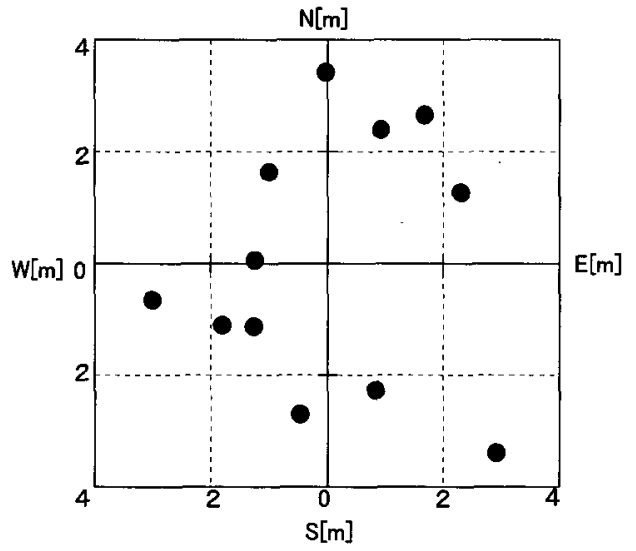

図 31 年間の測位結果のばらつき 2004年 1 月一 2004 年 12 月

表 4 三角点における測位結果

\begin{tabular}{|c|c|}
\hline 測位点 & $\begin{array}{l}\text { 四等三角点 牧/原 } \\
2002 \text { 年 } 8 \text { 月29日 }\end{array}$ \\
\hline $\begin{array}{c}\text { 緯 度 均 } \\
2 \sigma\end{array}$ & $\begin{array}{l}34^{\circ} 48^{\prime} 37.7390^{\prime \prime} \\
0.0233^{\prime \prime}\end{array}$ \\
\hline $\begin{array}{c}\text { 経 度 平均 } \\
2 \sigma\end{array}$ & $\begin{array}{l}138^{\circ} 07^{\prime} 43.4701^{\prime \prime} \\
0.0545^{\prime \prime}\end{array}$ \\
\hline $\begin{array}{c}\text { 高さ }[\mathrm{m}] \text { 平均 } \\
2 \sigma\end{array}$ & $\begin{array}{l}210.5 \\
0\end{array}$ \\
\hline 水平面 $2 \mathrm{dRMS}[\mathrm{m}]$ & 1.56 \\
\hline PDOP 平均 & 1.9 \\
\hline
\end{tabular}

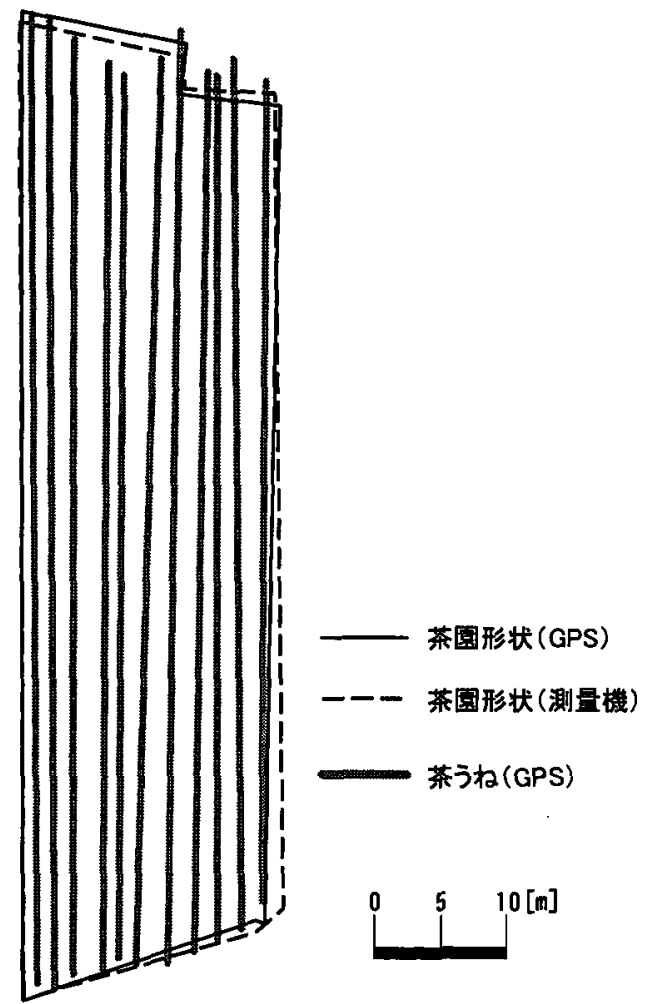

図 4 GPSによる茶園形状、面積、うね配置 の取得

茶園面積13.5a，11うね 
定するまでの 3 分間と茶園形状7点, うね配置 22 点の計29点を取得する10分間とで, 計13分 であった。単独測位GPSおよび測量機により

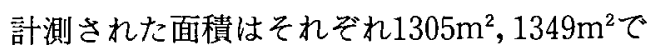
約 $3 \%$ の誤差が生じた。形状は測量機により 取得した形状とほほ同等であり，7点の各頂 点間の距離の誤差は平均 $0.69 \mathrm{~m}(\mathrm{n}=21)$, 最 大 $1.77 \mathrm{~m}$, 最小 $0.05 \mathrm{~m}$ だった（図 5 )。面積お よび茶園形状の取得において生じた誤差は, 測位結果のドリフトなどの単独測位GPS自体 の不確定の誤差による精度の限界と考えられ た。また, 2004年の毎月の測位結果の $2 \mathrm{dRMS}$ を考虑すると, 面積計測には不安定である。 うね配置図と茶園図とを合わせた場合，うね が茶園外に表示され，うねの配置を取得する には十分な精度はなく, 測量機の代替として の利用には不十分と判断された。

国土地理院発行の地図の精度は $1 / 25000$ 地 形図で図上 $\pm 0.7 \mathrm{~mm}$ (約 $\pm 17 \mathrm{~m}), 1 / 2500$ 国土 基本図で図上 $\pm 0.7 \mathrm{~mm}$ (約 $\pm 1.7 \mathrm{~m})$ であるか ら，単独測位GPSにより取得した位置情報は ほほ $1 / 2500$ 国土基本図に相当する情報と考え られる。したがって, 縮尺の大きな地図やコ ンピュータディスプレイ上で地図を搪大でき るGIS構築への適用には精度が不足するが, 茶 園での観察記録の位置情報・日時情報記録な

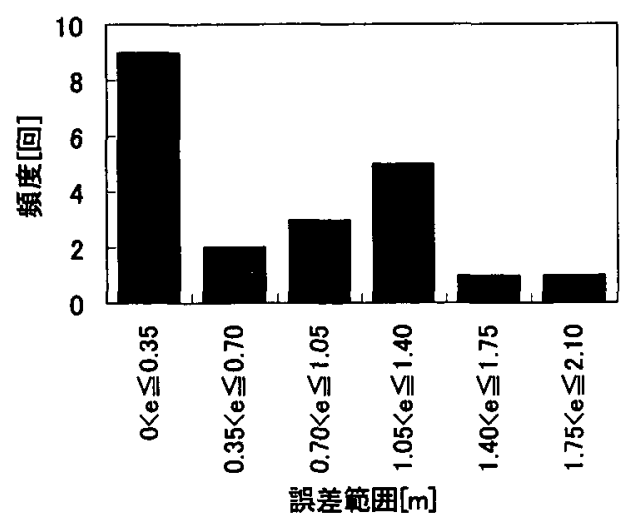

図 5 GPSによる茶園頂点間距離計測にお ける誤差頻度 $(n=21)$

茶園面積13.5a，11うね，7頂点

e :GPSによる点間距離計測の誤差 [m]
どへの利用が可能と考えられた。縮尺の小さ な地図,例えば $1 / 2500$ の地図を利用する場合, 単独測位GPSを茶園の特定や誘導に利用でき ると考えられた。

\section{4 摘 要}

本研究では, 単独測位GPSの測位精度を調 查し, 茶園面積計測やGISの構築など茶園管理 への利用を検討し, 以下の結論を得た。

1）アンテナ上空の状況により, 衛星からの 信号の受信状態が劣化し, GPSの利用に 適さない時間帯が出現する。

2) 良好な条件下での単独測位GPSの精密さ

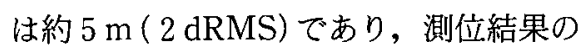
再現性は，年間を通して半径約 $6 \mathrm{~m}$ (2 dRMS) であることを確認した。

3) 三角点において測位した結果, 誤差は南 北 (緯度) 方向で $1.21 \mathrm{~m}$, 東西 (経度) 方 向で $0.645 \mathrm{~m}$, 距離で $1.37 \mathrm{~m}$, 高さで 3.24 mであった。

4) 約 $13.5 \mathrm{a}, 11$ ねの茶園の茶園形状, 面積, うね配置を取得した結果，うねの配置を 取得するには十分な精度が得られなかっ たが，茶園面積は $3 \%$ の誤差で取得でき た。また, 茶園形状は測量機により取得 した形状とほほ同等であった。

5）GISを構築するには精度が不十分である が, GISを運用していく上で茶園の特定な どに利用できると考えられた。

\section{5 引用文 献}

1) 坂井丈泰 (2003)：総合誤差. GPS技術入 門, 東京電機大学出版局, 95-98.

2 ）長坂善貞・谷脇憲 - 大谷隆二・重田一人・ 佐々木泰弘 (1999)：自動走行田植機の開 発 (第 1 報), 農 業機械学会誌61(6), 179-186.

3 ）木瀬道夫・野口 伸 - 石井一暢 - 寺尾日 出男 (2001)：RTK-GPSとFOGを使用 したほ場作業ロボット(第 1 報), 農業機 械学会誌 63(5), 74-79.

4) 木瀬道夫 - 野口 伸 - 石井一暢 - 寺尾日 出男 (2001)：RTK-GPSとFOGを使用 
したほ場作業ロボット(第 2 報)，農業機 械学会誌 63(5)，80-85.

5 ）木瀬道夫 - 野口 伸 - 石井一暢 - 寺尾日 出男 (2002)：RTK一GPS とFOGを使用 したほ場作業ロボット(第 3 報), 農業機 械学会誌 64(2), 102-110.

6）木瀬道夫 - 野口 伸 - 石井一暢 - 寺尾日 出男 (2002)：RTK一GPSとFOGを使用 したほ場作業ロボット(第 4 報)，農業機 械学会誌 64(4)，76-84.

7 ) 水島 晃・野口 伸・松尾陽介 (2004)： GPSを使用した車両方位計測法，農業機 械学会誌 66(6), 136-143.

8) 安田典夫 (2001)：GPSを搭載した農耕地 の土壤調查支援システムの開発, ペドロ ジシト 45(1), 14-22.
9) 土屋 淳・辻宏道 (1999)：3.1.4日本測地 系とWGS一 84 系. 改訂版GPS測量の基 礎，日本測量協会，62-63.

10）樋口良彦(2002）：農業土木におけるGPS 利用技術（その 5 ), 農土誌, 70(2), 147-150.

11）奥山武彦・奥島修二・中里裕臣・今泉畺 之・竹内睦雄 (1998)：ディファレンシャ ルGPSの測位精度と野外調查への応用の 検討, 農業土木学会論文集194, 149-157.

12）国土交通省国土地理院 (2004)：ネット ワーク型RTK一GPSを利用する公共測量 作業マニュアル(案) 基準点測量, 12 .

13）土屋 淳・辻宏道 (2001) : 3.1.2単独測位 の精度，そして誤差，新・やさしいGPS 測量, 日本測量協会, 116-117. 